3. Lye D, Dufour A. Virulence characteristics of heterotrophic bacteria commonly isolated from potable water. Environmental Toxicology and Water Quality: An International Journal 1993;8:13-23.

4. Rusin PA, Rose JB, Haas CN, Gerba CP. Health significance of pigmented bacteria in drinking water. Wat Sci Tech 1997;35:21-27.

5. Rusin PA, Rose JB, Haas CN, Gerba CP. Risk assessment of opportunistic bacterial pathogens in drinking water. Rev Environ Contam Toxicol 1997; 152:57-83.

6. Swimming pools, Section 9213B. In: Eaton A, Clesceri L, Greenberg A Franson M, eds. Standard Methods for the Examination of Water and Wastewater. 19th ed. Washington, DC: American Public Health Association; 1995:9-26-9-28.

7. Buck AC, Cooke EM. The fate of ingested Pseudomonas aeruginosa in normal persons. J Med Microbiol 1969;2:521-525.

8. Disinfectant residual in the distribution system. Federal Register June 29, 1989;54:27495.
9. Rutala WA, Weber DJ. Water as a reservoir of nosocomial pathogens. Infect Control Hosp Epidemiol 1997;18:609-616.

10. Piper J, Tuttle D, McGrail L, Steel-Moore L, Bollinger E, Berg D. P aeruginosa outbreak in a neonatal ICU due to construction related water line alterations. Proceedings of the 37th Interscience Conference on Antimicrobial Agents and Chemotherapy; September 27, 1997; Toronto, Ontario, Canada.

11. Bert F, Maubec E, Bruneau B, Berry P, Lambert-Zechovsky N. Multiresistant Pseudomonas aeruginosa outbreak associated with contaminated tap water in a neurosurgery intensive care unit. J Hosp Infect 1998;39:53-62.

12. Drinking Water System Components-Health Effects. Developed by the consortium of the American Water Works Association Research Foundation, the Association of State Drinking Water Administrators, the American Water Works Association, the US Environmental Protection Agency Under Cooperative Agreement \#CR-812144. Ann Arbor, MI: American National Standard/NSF International Standard; 1995:5-6,9-10. Appendix D.

\title{
Risk Factors for Antibiotic-Resistant $E$ coli Isolated From UTI Patients
}

\author{
Gina Pugliese, RN, MS \\ Martin S. Favero, PhD
}

Sotto and colleagues have reported on the results of a prospective study to evaluate the prevalence of resistance to penicillins, cephalosporins, carbapenem, quinolones, aminoglycosides, and trimethoprim-sulfamethoxazole (SXT) in 320 Escherichia coli isolates obtained from hospitalized patients with acute urinary tract infections (UTIs). The study period was from November 1998 to February 1999. They also studied these strains for risk factors for resistance to amoxicillin-clavulanic acid (AMC), fluoroquinolones (FQs), and SXT.
Resistance rates were consistent with those from major recent studies reported in the literature. Multivariate analyses selected the following factors as being significantly associated with $E$ coli resistance: (1) for resistance to AMC, prior (1 year) UTI (odds ratio $[O R]=2.71$ ), prior (1 year) urinary catheter $(\mathrm{OR}=2.98)$, and prior (6 months) antibiotic exposure (OR=2.68); (2) for resistance to $F Q s$, male gender (OR=3.87), with a trend toward significance for age $>65$ years $(\mathrm{OR}=7.67)$, and prior (1 year) UTI (OR=2.98); (3) for resistance to SXT, male gender $(\mathrm{OR}=1.91)$, hospitalization in an intermediateterm-care unit $(\mathrm{OR}=2.18)$, and prior (1 year) UTI $(\mathrm{OR}=2.03)$.

The authors indicate that the results suggest prior UTI is a common risk factor for resistance to the different antibiotics tested. Although few studies on risk factors for $E$ coli resistance to antibiotics have been published, careful interpretation of their findings, taking into consideration the population, infection site, and period studied, should contribute to the formulation of a better strategy that can be used to overcome antibiotic resistance.

FROM: Sotto A, De Boever CM, Fabbro-Peray P, Gouby A, Sirot D, Jourdan J. Risk factors for antibioticresistant Escherichia coli isolated from hospitalized patients with urinary tract infections: a prospective study. I Clin Microbiol 2001;39:438-444. 